Supporting information

\title{
Assessment of microalgal-bacterial granular sludge process for environmentally sustainable municipal wastewater treatment
}

Bin Ji a , Yu Liu ${ }^{b *}$

a Department of Water and Wastewater Engineering, Wuhan University of Science and Technology, Wuhan, 430065, China

b School of Civil and Environmental Engineering, Nanyang Technological University, 50 Nanyang Avenue, Singapore, 639798, Singapore

* Corresponding author. School of Civil and Environmental Engineering, Nanyang Technological University, 50 Nanyang Avenue, Singapore 639798, Singapore.

Tel.: +65 67905254; Fax: +65 67910676; E-mail: cyliu@ntu.edu.sg

(a)

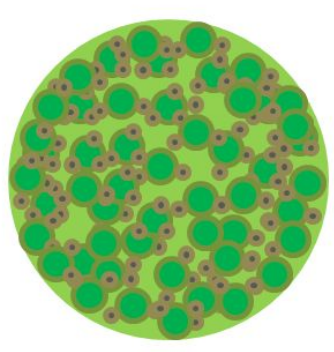

(b)

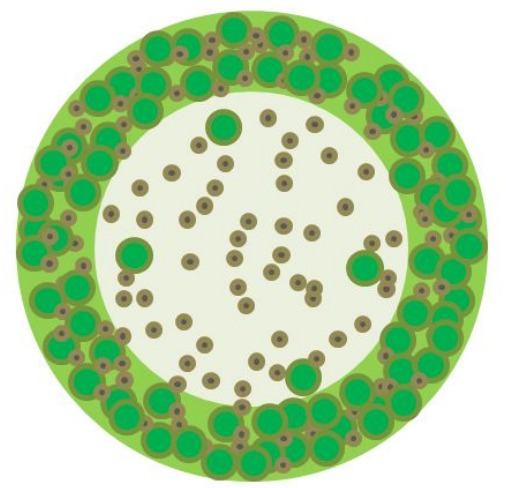

Microalgae

- Bacteria

Fig. S1 MBGS with a uniform structure (a) and layered structure (b). 


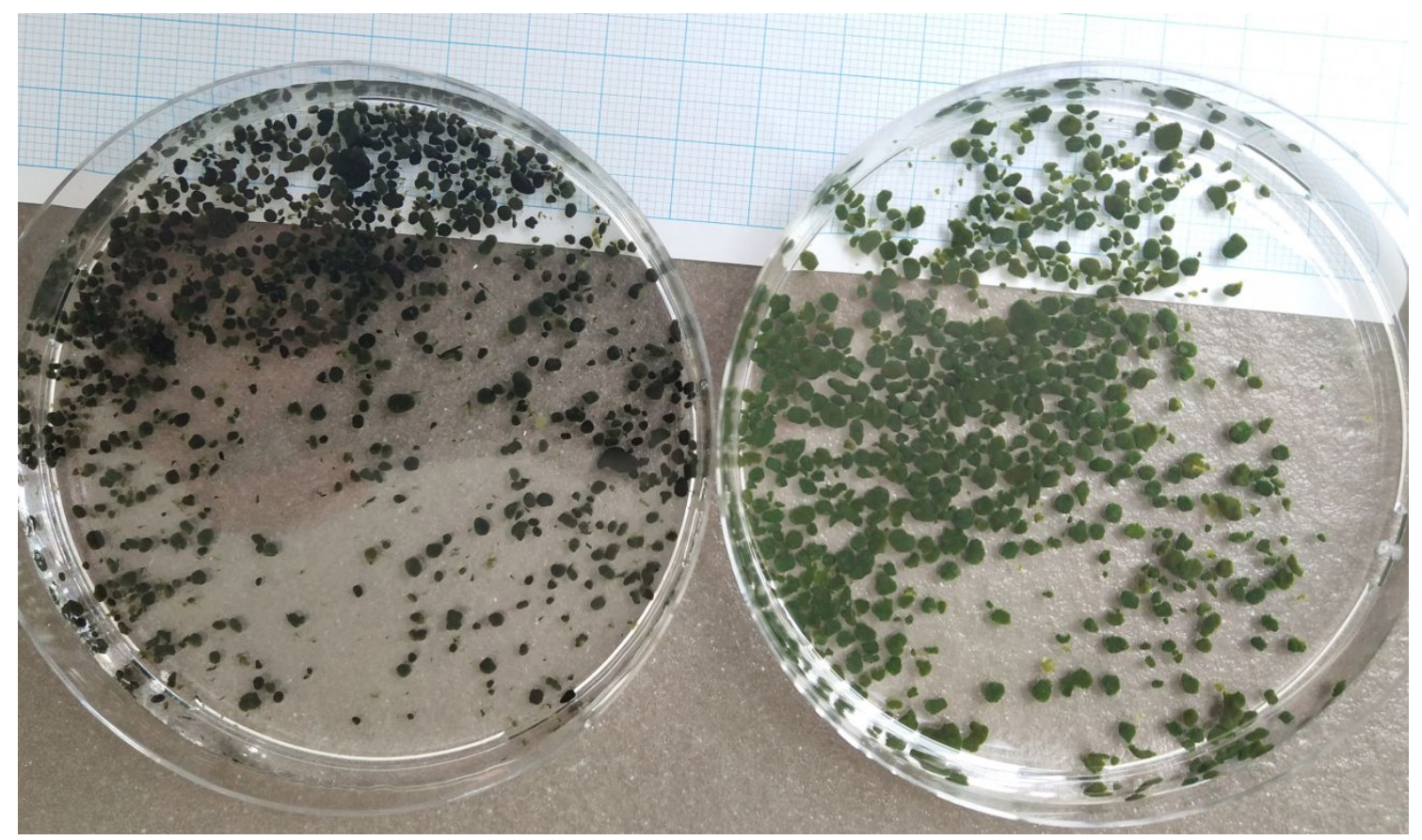

Fig. S2 Prokaryotic filamentous microalgae dominated MBGS (left) and eukaryotic microalgae dominated MBGS (right). 